UDC 82

DOI https://doi.org/10.24919/2308-4863/35-2-27

\author{
Ivan ZYMOMRYA, \\ orcid.org/0000-0003-3211-8268 \\ Doctor of Philological Sciences, Professor, \\ Head of the Department of Theory and Practice of Translation \\ Uzhhorod National University \\ (Uzhhorod, Ukraine) ivan.zymomrya@uzhnu.edu.ua
}

\author{
Olena KOLIASA, \\ orcid.org/0000-0001-5301-480X \\ Candidate of Philological Sciences, \\ Associate Professor at the Department of Germanic Languages and Translation Studies \\ Drohobych Ivan Franko State Pedagogical University \\ (Drohobych, Lviv region, Ukraine) olenakoliasa@gmail.com
}

Olena ZYMOMRYA,

orcid.org/0000-0001-7206-0190

Candidate of Philological Sciences,

Associate Professor at the Department of International Communication

Uzhhorod National University

(Uzhhorod, Ukraine) olena.zymomrya@uzhnu.edu.ua

\title{
THE INFLUENCE OF PERSONAL MOTIVE ON THE DEVELOPMENT OF THE PLOT CONCEPT IN THE PROSE OF JOSEPH CONRAD
}

In the substantial body of criticism written about almost every aspect of the novels of Joseph Conrad (1857 - 1924) there is a lack of comment about the influence of personal motive on the development of the plot concept in the prose of the famous Polish-British writer. Until the first half of the twentieth century, J. Conrad was considered a writer of stories about the sea and was recognized thanks to the use of symbolism and picturesque speech. The main aim of the present research is to show that literary works and Conrad's life are intertwined. The goal is also to present that only the combination of themes and symbols from a literary work 'The Heart of Darkness' is complete and fully reflects the value of Conrad's work. The objective of the study is built on literary aspects of the novella that are the part of the present research. The intention is to reveal that symbols, motifs and themes in the text 'The Heart of Darkness' are interrelated as well. It should be mentioned that his fundamental theme is the solitude of the individual and the sea is often chosen as a symbol. It will be mentioned in the thesis that his characters are often placed in isolated or confined situations. Conrad's solitary hero is almost always a fugitive, marked by misfortune or remorse. The necessary element to understand stories written by J. Conrad is to understand their structure therefore this part revolves around various characters and events, but without omitting the main subject, that is, characteristics of his stories including unique style, symbolism, picturesque. Another important feature of the prose created by this author is his narrative. It should be noted that the events in his short stories are narrated indirectly. Also, he used an alternative type of narration. This means that an identical event is described from different points. The innovation of the research is that elements related to themes and symbols are presented as a whole, not separately, as it has been presented by literary critics so far. The indication that Conrad's personal motifs influence the narrative composition of the novella also seems to be quite innovative.

Key words: Joseph Conrad's prose, personal motive, motif, symbol, symbolism, intertextuality.

Іван ЗИМОМРЯ, orcid.org/0000-0003-3211-8268 доктор філологічних наук, професор, завідувач кафедри теорї та практики перекладу

Ужггородського національного університету (Уэсгород, Украӥна) ivan.zуmотrуa@uzhnu.edu.ua

олена КОЛЯСА, orcid.org/0000-0001-5301-480X кандидат філологічних наук,

доцент германських мов і перекладознавства Дрогобииького державного педагогічного університету імені Івана Франка (Дрогобич, Львівська обл., Україна) olenakoliasa@gmail.com 
life are intertwined. The goal is also to present that only the combination of themes and symbols from a literary work 'The Heart of Darkness' is complete and fully reflects the value of Conrad's work.

Presentation of the basic material of the research. Until the first half of the twentieth century, Joseph Conrad was considered a writer of stories about the sea and was recognized thanks to the use of symbolism and picturesque speech. Joseph Conrad was not recognized until he became a master of English literature, writing in a foreign language. He learned English when he was already an adult. It should be mentioned that his fundamental theme is the solitude of the individual and the sea is often chosen as a symbol. It will be mentioned in the thesis that his characters are often placed in isolated or confined situations. Conrad's solitary hero is almost always a fugitive, marked by misfortune or remorse. The author wrote novels, short stories, and novellas referring to the struggle of the human spirit represented in an indifferent universe, with original prose that introduces a tragic non-English sensibility into English literature (Sikorska, 2002).

It should be mentioned that the term story is defined by its origin, form, and content. This genre has always competed with the novel. When in the twentieth century the short stories evolved in very different currents and themes, Anglo-Saxon short fiction became more and more popular. As a result, Joseph Conrad adopted his books to realia of his time. Also, his interest in adventures became a starting point for topics of his many stories and novels. Joseph Conrad's novels tell stories of the sea and adventure, stories of men who live next to the waves, and who face the extraordinary solitude of infinite and treacherous waters. His biography may explain a choice of similar themes for his novels. Joseph Conrad was born as Józef Konrad Korzeniowski in 1857. His father was a writer, translator, and political activist, who was known above all, for patriotic tragedies and translations from English. He encouraged his son to read a lot in Polish and French. As a result, Conrad as a young boy found a love of reading famous British literature, including literary work of Shakespeare, Charles Dickens, and Victor Hugo. In the past, Conrad was seen as a dreamer who had learned French, and later he started to learn English for professional needs. His passion for learning and reading caused many people, including his father, saw his career in a positive light. As a consequence of his life devoted to reading, he later became one of the greatest writers of the twentieth century (Meyers, 1991).

At the age of seventeen, driven by an irresistible vocation for sea life, he left his land and reached
Marseilles, where he embarked as a simple sailor. Navigation meant a lot to him. It meant knowing the world of the sea that was identified in trafficking and smuggling. He met men who embarked to escape and he saw the advantages and disadvantages of such a life. It meant, in short, to meet the worlds that stood at the antipodes of civilized Europe, but not just geographically. After doing regular practice in his work, he served as a deck officer and then as a captain on British merchant ships for a long period. During that time, he took advantage of traveling to the Far East, India, Borneo, and Sumatra. Long travel caused his real interest in writing. He had numerous occasions for experiencing and writing at the same time when he was away from home (Meyers, 1991). Conrad had an adventurous life and was involved in the arms trade and political conspiracies. These episodes he described later in one of his novels: «The Arrow of Gold».

During his life as a sailor, he also found himself on board a ship that had been shipwrecked, forcing the future writer to spend more than twelve hours on a lifeboat. This experience will then be described in another story («Youth»). In 1883 he embarked on «Narcissus» in Bombay, and from that trip, he took inspiration for the next novel "The Nigger of the Narcissus» which was written in 1897. The latter is considered an allegory of isolation and solidarity at sea. The navigation in the South Asian archipelago will provide him with the material for the other novels such as «An Outcast of the Islands》 and «Lord Jim» (1900). The trip to the coast of Venezuela will be remembered in "Nostromo», in which the first officer of the vessel will become the model for the characterization of many sailors' protagonists of his writings. Conrad will achieve another success with «The Shadow-Line» (1917), an absolute masterpiece, which has become the emblem of the difficulty of growing up and of what this passage entails.

As can be seen, Conrad's life experience influenced his numerous literary works and became the inspiration for writing this work. His family was originally from a part of Poland annexed to Russia therefore he had grown up in the dream of sailing the seas in freedom, far from the land that had caused so much pain. When he obtained British citizenship his next years were more satisfying for him. For twenty years he will travel for almost all the seas, but especially in the Malay archipelago. Finally, it had led him to leave the navy to devote his life to literary activity.

Further study is devoted to an analysis of selected literary works. Based on Conrad's great works of universal literature, this research aims at focusing on a style of his writing that is a subject of study. The nec- 
essary element to understand stories written by Conrad is to understand their structure therefore this part revolves around various characters and events, but without omitting the main subject, that is, characteristics of his stories including unique style, symbolism, picturesque. Another important feature of the prose created by this author is his narrative. It should be noted that the events in his short stories are narrated indirectly. Also, he used an alternative type of narration. This means that an identical event is described from different points.

All characteristic features of his short stories contributed to his achievements in literature. In this sense, the author has been positively remembered as the creator of modern works. His literary work together with various events and characters creates a deep philosophical reflection that gives the psychological sense of his stories. Conrad's prose focuses on stylistic peculiarities therefore the research describes many stylistic expressive means which can be found in Conrad's books. Although one can see many of them, some linguistic features can be unnoticed because the author uses them in the minority, such as neologisms. Taking this into account, Conrad's literature is difficult for reading.

Undoubtedly, the author tries to be one of the most precise and sophisticated in English, but his work leaves much to be considered as the best example of the style. He uses specific means such as words or expressions which are not used in English by other writers. All this distinguishes his literary work because books are difficult to read for ordinary readers.

Moreover, Conrad was able, thanks to rich language, to recreate exotic atmospheres in a masterly way and reflect the doubts of the human soul in contact with wildlands. His reflections reveal a pedagogical approach to his stories. While the British Empire reached its peak, Joseph Conrad used his experience, first in the French navy and later in the British, to write novels and stories that reflect aspects of a global empire and, at the same time, he could explore the abysses of the human mind. The psychological aspect of his novels reveals Conrad's interest in answering important questions about the human soul and shows the conflict between various people based on the characters in his books.

Between 1894 and 1924, he published his great novels, linked to the experiences and adventures he had experienced along the seas all over the world. Conrad is now universally recognized as one of the great masters of English prose, and although many of his works present elements of romantic inspiration, he is considered above all an important precursor of modernist literature, which would later influence several European and American writers. His symbolic and evocative language is influenced by the other languages he knew, Polish and French, which gives an exotic look to his English, which seems unusual even when it is grammatically incorrect. In his many stories, Conrad also shows the revolutionary stages of the unconscious, which at times seem to anticipate the technique of «stream of consciousness». The financial success of writing had not failed in Conrad. His health remained precarious for the rest of his days, but he continued his literary work till his death in 1924. The writer was buried in the cemetery of Canterbury (Kent, England), with the name of Korzeniowski (Meyers, 1991).

Results and discussions. Of all the literary genres, it is possibly the story, by its origin, form, and content, the one that has maintained the most connection with human events. At the outset, it should be explained that we distinguish two large groups: traditional (orally transmitted) and later collected in a literary way in books, and modern ones, which were born in the nineteenth century, especially from the work of Edgar Allan Poe. The author found the most relevant model of the story. In the twentieth century, although the short stories evolved in very different currents and themes (Anglo-Saxon short fiction, the vigorous Spanish-American tale, the important Italian storytellers, the current literary works that develop from the work of Kafka, etc). Undoubtedly, Poe is still a paradigm of what a good modern story should be. What is more, the short story competes with the novel. The novel is, relativizing an affirmation of this kind, a much more recent literary genre, which development is related to that of the printing press because it is intended for reading against the original oral character of the story. Its appearance coincides with the end of medieval theocentrism and the access of Renaissance anthropocentrism.

In the beginning, this new genre owes a lot to the stories in its birth and traditional stories. Thus the first novels achieved success thanks to several stories, although they are not only this, and they add other elements that constitute their peculiarity, as a distinct form of the story. Maybe it is because of this circumstance, or simply because of literary criticism, the reason why we tended to consider the novel as a long story and the story as a very short novel is clear. Either of these two approaches can be understood. Each type of story, novel, or short story, requires a specific technique. To write stories, good stories, the best thing can be to leave oneself lead by the storytelling intuition (if it exists), of that narrative capacity that affects us with the oral story of a more or 
less remarkable fact. In this sense, it may be worth remembering the influence that Edgar Allan Poe realized before anyone else of the rigour that the story demands as a genre, and that its differences with the novel were not just a matter of brevity.

The difficulty of writing stories, lies, undoubtedly, in that its complex and precise structure which makes it difficult to write the short story. In comparison to the short story, their genres have less rigid rules, such as the novel or the poem.

An important feature of the prose created by this author is the indirect narrative. It should be noted that the events in his short stories are narrated by the narrator, who is also the hero of the book. Besides, another element of the short story is a narrative of another type, e.g. alternative type of narration. This means that an identical event is described from different points. All characteristic features of his short stories in mind contributed to his achievements in literature. In this sense, the author is remembered as the creator of modern novels. His literary work together with various events and characters creates a deep philosophical reflection that gives the psychological sense of the stories.

It is worth mentioning more about genre specifics of Joseph Conrad's short stories. When it comes to «The Heart of Darkness», the author gave a symbolic title to his literary work (Anderson, 2005: 3). There is the element of dark and the lack of sensitivity. It is connected to human existence and seeing the world in only two colours: black and white. Like other short stories, there is more than one narrator in the book. At the time of colonialism in Congo, Marlow was the protagonist and tells some friends' experience in Congo. They are located on the Thames with a unique landscape. The fact is that a small boat is a perfect place to make room for the memories. It could be an inspiration for the author. The structure of the book is intertwined with the hidden narrators telling the story. The theme is extremely interesting therefore the short story is treated as a masterpiece. The reader can find the description of colonialism, often fierce, very similar to an armed robbery and elements of racism. This manifestation of racism can be seen as very early (Clarke, Scorgie-Porter, 2017). On a journey to nowhere, going up the river to get into the heart of darkness, Marlow discovers that in front of the station «dominated» by Mr. Kurtz there are people killed «A black man killed by arrows shot by the natives» (Conrad, 2012). This cruel act reveals how human wickedness exceeds all limits. It should be explained that was hired by an airline to replace a captain killed by the natives. With great skill, Conrad exposes the reader to his essentially ambiguous story where his blatant anti-imperialism is accompanied by ideas and vaguely racist passages.

While reading the story, almost two narrative voices can be heard. On the one hand, Marlow with his direct voice tells the story; on the other hand, the other narrator puts outside the world with a more stable and firm voice. It should be emphasized that the narrative of Marlow is highly emotional. He can describe the horror of colonization done by white men. Besides, the most significant part of the book revolves around the figure of Kurtz.

What is more, there is a psychological aspect in many short stories written by Joseph Conrad therefore readers may make a typical analysis of some characters. In his famous short story «The Heart of Darkness» also refers to psychological considerations of the characters and their actions in the book (Anderson, 2005: 37). For example, Kurtz, who initially was driven by good intentions, end up being an exploiter thirsty only for wealth and power. The lust for ivory dominated him very much. He hated black people, who, it seemed to him, protected the black continent. Initially, the primary product which profited ivory was obtained in large quantities by hunting on elephants. From 1887, after the outbreak of the «rubber boom», the demand for this product is multiplied. Because of inhuman practices and mass hunting, the problem presented in the book can be seen clearly. Certainly, this person seems to be almost insane bloodthirsty. Kurtz represents evil in the book. The horror can be spotted based on the difficulties, critical situations, assaults. In the end, a sick man, almost a ghost, is discovered as a colonialist visionary and an additional symbolic step in the book. On the trip back, Marlow will be able to perceive the last words of Kurtz: «The horror! The horror!». These are the words that reveal the terrible reality of colonialism. "The Heart of Darkness»" presents the dark side of society and propensity for racism (Clarke, Scorgie-Porter, 2017). It is the story of European colonialism and black Africa, too. The character of Kurtz is almost associated with madness. He does not longer control his actions. As a result of this, it brought him nothing good. It can be seen that not only madness but also bitterness reigns over man.

In many short stories, the landscape is one of the keys and it has significant value for the writer. The geographic elements of the region influenced not only Marlow (the character described above in the context of the mentioned story), but also Kurtz and other characters.

Therefore, to understand how important the environment in the story is, the reader must first consider how it is presented by Conrad. The writer presents a wild place, a place that hides the unknown truth: «a 
thing monstrous and free». The essential theme of literature and philosophy of the late nineteenth century and important to the author was to describe a place to hide the true essence. Throughout the book, many racist elements can be seen. Bearing it in mind, the African world is described even darker than the Romans found, e.g. "Light came out of this river since [...] but it is like a running blaze on a plain, like a flash of lightning in the clouds. We live in the flicker-may it last as long as the old earth keeps rolling! But darkness was here yesterday» (Conrad, 2012: 6). According to Marlow, the jungle is «the grove of death». In many similar descriptions, there are many elements of racism (Clarke, Scorgie-Porter, 2017).

Moreover, the problem of colonialism is a simple question that has never had an adequate answer. Marlow tells lies to Kurtz's girlfriend that his last words before he died were meaningful. He called her name because he wanted to give the impression that Kurtz could be an emotional man - not always bad. What is more, a lie to continue to live, to love, to dream, and to forget the horror was mentioned. Undoubtedly, «The Heart of Darkness» is recognized as a literary work that is full of history and painful truth therefore realism can be seen there. Realism is typical for this literary genre.

Besides, the experience is perhaps the most valuable witness of the adventure as it was said by Conrad. To prove this, the following words are used: «The Heart of Darkness» is experienced... pushed a little (and only very little) beyond the actual facts of the case. Hence, the African bush is presented as something wild, primitive, as the ultimate expression of irrational impulses. It is, in short, a scenario where no prevailing laws and rational order exist, where a man can behave in the same way as Kurtz does. In other words, it is the world where everything may be hidden, even amoral acts. A multitude of examples that provide racism occurs in the book.

As can be seen in the short story as a literary genre it refers to universal topics. These topics are essential from a human point of view. But, the journey of this particular story should not only be seen as a simple physical displacement from point A (London) to point $\mathrm{B}$ (the jungle of Congo) with consequent geographical and anthropological description. It should be maintained that the journey goes much further than a place other than the earth. It is investigated and revealed a different era of human development, to a more primitive stage of man. It may be explained that it is not the reasoning, but the instincts of a man - to make the decisions. It is a shift from light to darkness, from civilization to barbarism. This rational thought describing the instinctive human unconscious can be seen in the book.
At this point, Marlow returns to an earlier stage of human development at the present civilization by saying: "We were wanderers on a prehistoric earth, on an earth that wore the aspect of an unknown planet》 (Conrad, 2012: 40). Besides, the river is much more than a river path. It is a way for the life of man, which leads to personal knowledge and the deepest, darkest self territories. Besides portraying the bestiality of the untouched territory, the dark nature of the human can be found. For the first time, Marlow had a typical colonial vision, when he had been in Europe. He imagined the natives as the enemy. Later, he started to realize that: "They Were not enemies, They Were not criminals, They Were nothing earthly now, - nothing but black shadows of disease and starvation» (Con$\mathrm{rad}, 2012: 18-19)$. It is emphasized that it is difficult to be the enemy who cannot defend himself. In the next step of the story, Marlow not only changes the perception of native, but he also changes the perception of nature. He notices the beauty of the land: «I've never seen anything so unreal in my life» (Conrad, 2012: 26). The environment begins to look like something imaginary, a blur, like pieces of a dream. This change in perception, or assimilation of nature, it is considered madness in the West, because all the mental structure of a civilized and rational man is lost. But this «madness» is not unusual in the jungle, but in the West, it is regarded as a mood or illness. The same happened with Kent, who lost control of his consciousness. His madness was seen not as a disease. It was the instinctive step for a man to assimilate nature. What is more, is simply nature and solitude appropriating the mind of a civilized man? It should be assumed that «His soul was mad. Being alone in the wilderness, it HAD Looked Within itself, and, by heavens! I tell you, it HAD gone mad» (Conrad, 2012: 77). Human nature requires existing soil and control all around. Both domination and murder as the elements of drama mentioned earlier in this thesis are presented as examples of «the fittest» and «natural». The same arguments are used by Europeans to justify colonization in a very ironic way (Carr, 2014: 41).

Characters in Joseph Conrad's short stories undergo a big change. Kurtz is also portrayed in the light of the transformation. Ones, he was presented as a person who is not a racist, later he became a cruel racist human. Mixed feelings are presented in light of every day. The darkness of the jungle learned him and gave him the best: «It had taken him, loved him, embraced him, got into His veins, Consumed His flesh, and sealed His Soul con sus own by the inconceivable ceremonies of some devilish initiation» (Conrad, 2012: 55). Kurtz understood that the only way to survive is to join reality - nature; otherwise, nature will 
be your worst enemy. The book can be an example of a real battle of words and opinions among those who are racist and those who are not. The impact of «The Heart of Darkness» was so great that it was adapted several times by the imitators of the author.

Conclusions. Joseph Conrad is recognized as a versatile and prolific writer. He published many novels, short stories, and essays. The literary output of the author is important because of its timelessness and the internal strength of the individual characters. Life on the sea and in foreign ports is a background for almost all of his stories, but his basic obsession as well the major theme in his works was the human condition and the fight of the individual between good and evil. These opposites have always been taboo in novels. However, the author was able to combine these opposites with an interesting form of narrative and individual style of writing. His literary output is full of stylistic peculiarities, symbolism, and pictoriality.

His most famous novel «The Heart of Darkness» is the demonstration of the subjectivity of Conrad's narrative, a work full of psychological nuances and symbolism in which he uses his African experience to describe a journey across the Congo River. It is a journey into the depths of hell and hence a specific narrative that has a symbolic character. In the book, the jungle is an allegory of transforming a man into a primitive being dominated by his lower impulses. Conrad's books contain numerous descriptions of nature, dark landscape, jungle, brutality, and human weaknesses. Thanks to this novel, the author revealed the genocide that took place at that time in the Belgian Congo. He created a language that is difficult to read for the recipient and the present readers. Nevertheless, due to the difficulty of this writer, his work should be appreciated because they constitute a great literary value due to the timelessness of the novel, style, multitude of stylistic means, and the peculiar characters of the narrative.

What is more, the structural features of his works, especially the "The Heart of Darkness», are also worthy of special appreciation. This is because the plot keeps the reader in a state of excitement, offering a huge number of characters interconnected and involved in the conquest of African provinces. Besides, the many original themes, motifs, and symbols that intertwine in his novella merit attention. Unquestionably, Joseph Conrad's works are an achievement in the literature of the twentieth century.

\section{BIBLIOGRAPHY}

1. Anderson J. P. Conrad's Heart of Darkness: Rebirth of Tragedy. Florida: Universal Publishers, 2005. 180 p.

2. Carr W. The Representation of Women in Heart of Darkness. Sosland Journal. 2014. Issue 8. P. 39-46.

3. Clarke C., Scorgie-Porter L. An Image of Africa: Racism in Conrad's Heart of Darkness. New York: Taylor \& Francis Group, 2017. 88 p.

4. Conrad J. Heart of Darkness. London: Penguin Classics Deluxe Edition, 2012. 160 p.

5. Hochschild A. Stranger in Strange Lands: Joseph Conrad lived in a far wider world than even the greatest of his contemporaries. Foreign Affairs. 2018. Vol. 97. No. 2. P. 150-155.

6. Meyers J. Joseph Conrad: A Biography. New York: Charles Scribner's Sons, 1991. 428 p.

7. Sikorska L. An Outline History of English Literature. Poznań: Wydawnictwo Poznańskie, 2002. 541 p.

\section{REFERENCES}

1. Anderson J. P. Conrad's Heart of Darkness: Rebirth of Tragedy. Florida: Universal Publishers, 2005. 180 p.

2. Carr W. The Representation of Women in Heart of Darkness. Sosland Journal. 2014. Issue 8. P. 39-46.

3. Clarke C., Scorgie-Porter L. An Image of Africa: Racism in Conrad's Heart of Darkness. New York: Taylor \& Francis Group, 2017. 88 p.

4. Conrad J. Heart of Darkness. London: Penguin Classics Deluxe Edition, 2012. 160 p.

5. Hochschild A. Stranger in Strange Lands: Joseph Conrad lived in a far wider world than even the greatest of his contemporaries. Foreign Affairs. 2018. Vol. 97. No. 2. P. 150-155.

6. Meyers J. Joseph Conrad: A Biography. New York: Charles Scribner's Sons, 1991. 428 p.

7. Sikorska L. An Outline History of English Literature. Poznań: Wydawnictwo Poznańskie, 2002. 541 p. 